\title{
A frustração profissional e a lei
}

Gessé Marques Jr.

Acreditavam no que diziam. Qualquer pessoa demonstra uma deferência respeitosa perante certos sons que ela própria ou os seus semelhantes são capazes de emitir. Quanto aos sentimentos, porém, ninguém na verdade sabe nada. Falamos com indignação ou entusiasmo, falamos de opressão, crueldade, crime, devoção, sacrifício, virtude, e não sabemos o que existe de real por trás das palavras. Ninguém sabe o que significa o sofrimento ou o sacrificio exceto, talvez, as vítimas da finalidade misteriosa dessas alusoes. Joseph ConRaD, Um posto avançado do progresso.

Numa pesquisa realizada entre juízes e promotores públicos na região de Campinas, São Paulo, analisamos o modo como esses profissionais avaliavam a violência sexual e as agressões físicas que os estupradores costumam sofrer nas prisões. Partimos de uma regra de senso comum que afirma "quem entra com estupro, é estuprado", e, embora seja uma regra interna e não tenha formalização jurídica, é recorrente e efetiva na sua imposição violenta sobre os estupradores, submetendo-os a um contexto de sujeição, mando e violência dos pares. Contexto de dinâmica carcerária que se afasta das garantias formais e jurídicas da execução penal, de controle sobre a sexualidade e do direito de disporem do próprio corpo.

Independentemente de um padrão estatístico de recorrência das violências a que os estupradores estão sujeitos, o interesse da pesquisa orienta-se à avaliação dos juízes e promotores sobre esta regra não jurídica. Por meio dela, analisamos como interpretavam as obrigaçóes legais e o papel do Judi- 
ciário e do Ministério Público no controle e na efetividade das prescrições jurídicas em relação à fase de Execução Penal.

A reflexão e as ambiguidades dos juízes e promotores em relação à tutela do estuprador inseriam-nos em um conflito jurídico e prático envolvendo aquilo que está previsto no ordenamento, o não previsto, o lícito, o ilícito, as práticas desejadas e as práticas efetivas de punição e proteção desses indivíduos e da população carcerária.

Tendo como pano de fundo este contexto que envolve a vida carcerária, neste artigo veremos que ao compreenderem, avaliarem e interpretarem as condições das prisões e da execução penal, estes profissionais questionavam e nomeavam sentimentos e emoções que envolvem as práticas cotidianas das profissóes jurídicas. E, com o uso de entrevistas e pesquisa de campo, descobrimos um "sentimento de frustração" que percorre o conflito estrutural existente entre a ordem normativa e a realidade carcerária, entre o reino teórico e abstrato do "dever ser" juridicamente positivado e o mundo violento das práticas carcerárias. Sentimento que é resultado do trabalho emocional realizado por esses profissionais do campo jurídico.

O campo

A pesquisa de campo e a coleta de dados foram feitas entre os meses de julho a outubro de 2006. Distribuí questionários e realizei entrevistas abertas, recorrendo à metodologia de trabalho de campo dos estudos antropológicos (cf. Cardoso, 1986; Feldman-Bianco, 1987; Zaluar, 1985; Caldeira, 1988).

O trabalho de campo não permitiu o contato duradouro e de constante envolvimento com os entrevistados, como vemos em trabalhos de antropologia, especialmente a partir de Malinowsky. Mas, assim como ele, procurei alcançar os "imponderáveis da vida real e do comportamento típico" entre os nossos "nativos" (1984, pp. 28-31). Embora não atinja a riqueza de uma "descrição densa”, ou o "corpo e alma da magistratura”, o trabalho de campo procura entender - como Geertz - o homem como "um animal amarrado a teias de significados que ele mesmo teceu", desvendando essas teias e fazendo sua análise, "não como uma ciência experimental em busca de leis, mas como uma ciência interpretativa, à procura do significado". Nesse sentido,

[...] nossa dupla tarefa é descobrir as estruturas conceptuais que informam os atos dos nossos sujeitos, o "dito" no discurso social, e construir um sistema de análise 
em cujos termos o que é genérico a essas estruturas, o que pertence a elas porque são o que são, se destacam contra outros determinantes do comportamento humano (Geertz, 1978, p. 31-38).

As entrevistas foram realizadas com sete promotores (seis homens e uma mulher) e doze juízes (sete homens e cinco mulheres) com questôes abertas e tendo como roteiro os seguintes pontos: se haveria e quais os problemas jurídicos e processuais da violência contra o estuprador na prisão; se essa situação impunha constrangimentos ao Poder Judiciário, especialmente quanto à fase processual da Execução Penal; quais conflitos de competência surgiam entre o Poder Judiciário e o Poder Executivo na administração penitenciária; e, especialmente, como, a partir dos diferentes discursos apresentados, e de acordo com a "abertura” do entrevistado, era possível questionar os sentimentos que, individualmente, os diferentes operadores associavam às tarefas profissionais, ao fazer jurídico no cotidiano.

Deixei os entrevistados desenvolverem suas opiniōes, suas interpretações e fazerem as associações que julgavam pertinentes. Não utilizei gravador para evitar constrangimentos quanto à reserva pessoal e profissional, e para que a conversa pudesse fluir mais livremente; conforme o que aprendi na convivência no campo jurídico, se utilizasse gravador muitos recusariam a entrevista. Por outro lado, alguns entrevistados não se oporiam ao gravador, afirmando, expressamente, não se intimidarem em declarar suas opiniões pessoais. Tanto em um caso como em outro, esquivando-se ou revelando-se ostensivamente, existem dificuldades e constrangimentos profissionais formais e informais quanto a expressar a opinião sobre temas relacionados com o funcionamento da justiça e do direito (Brasil, 1979).

Devido ao contexto das relações no ambiente jurídico, à minha experiência como pesquisador e aos limites da interação com este campo, conforme eu realizava as entrevistas, anotava os principais pontos da discussão e opiniōes, transcrevendo e sistematizando-os posteriormente. Três juízes solicitaram a transcrição da entrevista para verificação e aprovação do seu conteúdo, devolvendo-as sem pedido de alterações.

Ao me apresentar, dizia que tinha formação e pós-graduação em ciências sociais e cursava mestrado em Direito. Se, de um lado, as ciências sociais me afastavam do campo jurídico, de outro, o mestrado me aproximava como um possível interlocutor, como alguém que poderia entender o vivido no sistema de justiça, ainda que não fosse reconhecido como um par. Dificuldade que não é somente minha, mas que também aparece em trabalhos 
sobre a magistratura que usam o distanciamento estatístico como forma de aproximação e coleta de dados (Vianna, 1997, 1999; Sadek, 2005, 2000, 1997, 1995).

Os juízes e os promotores entrevistados dispuseram de aproximadamente uma hora e meia para a entrevista. Embora possamos dizer que uma lógica formal e legalista percorre o discurso dos juízes e promotores, conforme íamos conversando e tratando dos problemas relacionados com a prática jurídica, alguns se soltavam e questionavam sua própria prática. Falavam de problemas pessoais, de problemas que envolvem o sistema de justiça, muitas vezes utilizando uma linguagem que os afastava dos limites de distanciamento, formalidade, reserva e "respeitabilidade" do jargão forense.

E eu, sociólogo em traje forense, vestido de terno e gravata e preso aos limites da formalidade desse campo, espantavam-me quando, mais relaxados(as), juízes(as) e promotores(as) diziam coisas do tipo "como juiz não faço 'porra' nenhuma”. Nesses momentos era como se eu pudesse atravessar os limites previstos na ordem formal-legal e, ansioso para entender seus sentimentos pessoais e profissionais, ver, como Lewis Carroll, o que ocorre do outro lado do espelho.

\section{O dever ser jurídico}

Antes de descrevermos alguns sentimentos que compõem a atividade profissional, é necessário expor certas variáveis teóricas que estruturam o campo jurídico, e constroem, orientam e limitam o pensamento e a ação dentro do Direito e, especialmente, no Direito Penal.

Ao analisar o Direito Penal, Bitencourt afirma que ele pertence à classe

[...] das ciências do dever ser e não à do ser, isto é, das ciências naturais. [...] É ciência normativa porque tem como objeto o estudo da norma, do Direito positivo. A Ciência do Direito Penal tem como objeto o estudo do conjunto dos preceitos legais, o "dever ser", bem como as consequências jurídicas do não-cumprimento dos preceitos normativos.

E, como ciência normativa e dever ser, "o Direito Penal é Direito positivo, na medida em que a sua obrigatoriedade não depende da anuência dos destinatários, mas da vontade estatal soberana que o impõe, e o seu cumprimento está garantido pela coerção, aliás, com a sua forma mais eloquente, 
que é a pena". De maneira sintética, Bitencourt afirma que "o Direito Penal positivo constitui-se do conjunto de preceitos legais que regulam a atividade soberana estatal de definir crimes e cominar as respectivas sanções” (2006, pp. 5-6, grifos do autor).

Essa visão positivista pode ser remetida a Hans Kelsen ao afirmar que o direito deve ser entendido "como um sistema de normas que regulam o comportamento humano", considerando normas algo que "deve ser ou acontecer", e a maneira pela qual os indivíduos devem se conduzir. $\mathrm{O}$ "conceito de dever jurídico refere-se exclusivamente a uma ordem jurídica positiva e não tem qualquer espécie de implicação moral" (1998, pp. 5-6; 131-133). O dever ser só pode ter como parâmetro a norma jurídica positivada pela legislação, sendo, portanto, diferente das imposições e obrigações socioculturais que, embora possam ter força coercitiva nas interações sociais, não têm caráter de sanção jurídica, fazendo parte da moral, dos costumes, e não do direito.

Em relação à sua validade, Dimoulis define a

[...] norma jurídica (ou regra jurídica) como uma proposição de linguagem incluída nas fontes do direito válidas em determinado país e lugar; seu conteúdo é fixado no âmbito da interpretação jurídica e objetiva regulamentar o comportamento social de forma imperativa, estabelecendo proibiçôes, obrigaçôes e permissões (2003, p. 63).

O fundamental nessa definição positiva do direito é que os operadores do direito - e especialmente o juiz, como destinatário da norma - não podem utilizar categorias que estejam fora do direito positivo, que é o direito posto e/ou imposto por uma vontade estatal soberana que define os crimes, as respectivas sanções e as formas de execução penal.

Para a interpretação positivista do direito, ou juspositivista, é fundamental a noção de dever ser, assim como a necessidade de não se confundir com o ser. Nestes termos, a norma jurídica mantém-se como dever ser ainda que ela não seja obedecida, pois a sua validade jurídica independe da sua aplicação. E, ao destinatário da norma, ao juiz, é imperativo que siga a regra e que não receba influências do ser a ponto de alterar a sua normatividade. "Os juspositivistas partem do pressuposto de que o ser não deve ser confundido com o dever ser. Isso significa que o direito, tendo qualidade de dever ser, não pode ser deduzido de algo fático, de elementos que existem no mundo do ser" (Dimoulis, 2006, p. 117). 
Nesta perspectiva, o sistema tem uma lógica interna de funcionamento que é necessário entender em seus próprios termos, tendo como referência suas regras, construídas de acordo com a hierarquia e os procedimentos previstos no próprio ordenamento jurídico. Ou seja, não importa que o dever ser não se realize totalmente na prática social, ou que o próprio sistema possa, em determinado momento, ser visto como injusto. O que importa são as regras positivadas no ordenamento pátrio que orientam, cerceiam e delimitam o quadro das açôes possíveis dos operadores do direito.

\section{O jurídico e a ação profissional}

Em sua pesquisa na comarca nomeada Branca, Maria da Glória Bonelli analisa os conflitos intraprofissionais (entre os próprios pares e estratificação profissional) e interprofissionais (entre profissóes distintas que atuam em áreas próximas) dentro do campo da justiça. Para isso, utiliza-se da ideia de sistema a fim de afirmar que essas profissóes têm como objeto comum a justiça, embora os diferentes profissionais, tais como advogados, funcionários do fórum, promotores e juízes, ajam de maneira diversificada, de acordo com a sua atividade.

A autora conclui que

[...] o que unifica os profissionais do campo da justiça, que se aglutinam em torno do Judiciário [é um] descontentamento com o Legislativo, [com o] estado da legislação e das leis processuais, consideradas ultrapassadas e inadequadas para o andamento eficaz do sistema judiciário. [...] Os conflitos com o Legislativo dão a dimensão de que os profissionais do Direito vinculados ao Judiciário constituem um campo diferenciado dos demais (Bonelli, 1998, pp. 201-202; ver também, 2005, 2001).

$\mathrm{Na}$ estruturação do campo vem à tona o conflito e o descontentamento com o Legislativo quanto à produção, à qualidade e aos limites que a legislação estabelece para a atividade jurídica. Essa avaliação impõe uma insatisfação exterior ao Judiciário, e a atribuição de problemas a outra competência de poder. Além desta característica, pretendemos demonstrar que o descontentamento e os conflitos são próprios à estrutura de racionalidade da profissão, pois, independentemente da qualidade da legislação, ela é o parâmetro da ação. É o dever ser abstrato e ideal, relativamente independente da realidade vivida e/ou percebida pelos profissio- 
nais, que sempre causa conflito com a realidade de sua aplicação, ainda que o descontentamento seja maior ou menor conforme a sua qualidade. Nesse sentido, a profissão jurídica é mediada pela insatisfação com a norma e com o dever ser jurídico abstrato - imposto pelo Legislativo -, confrontando-se com as práticas do Executivo, e, dentro dos contornos da nossa pesquisa, com a limitação da ação jurisdicional na realidade do sistema carcerário, no interior do processo de execução penal.

A estrutura de racionalidade do Direito gera um sentimento que é próprio desta atividade profissional. Ainda que, inicialmente, este dado não fizesse parte dos objetivos da pesquisa, por conta das respostas e dos diálogos que surgiram nas entrevistas, percebemos um discurso recorrente e obrigatório sobre o sentimento de frustração. De forma mais ou menos explícita, ou a partir de meu questionamento, os juízes e promotores afirmavam que suas atividades envolviam um ônus de frustração pessoal. E não importa se é o caso de uma emoção verdadeira, falsa, hipócrita, cínica, sofrida, sentida ou não. Importa que, além do dever de reserva e das atitudes ascéticas e aristocráticas que, entre outras, definem o habitus do campo do direito (Bourdieu, 1989, p. 227), é necessário expor a frustração, falar da frustração e muitas vezes se mostrar frustrado, como um modo de equilibrar, de refletir, de questionar a atividade, e de se colocar no mundo do direito - especialmente na Execução Penal -, dadas as impossibilidades da plena realização do dever ser jurídico.

Na pesquisa sobre trabalho e doença mental, Dejours (1992, p. 26) entende que a organização do trabalho cria um processo de anulação do comportamento livre e que os processos produtivos impóem doenças e sentimentos (Idem, p. 45). Para o autor, as doenças não se limitam ao sofrimento físico, mas deixam rastros e restos no sistema psíquico que são produtivos, pois "a erosão da vida mental individual dos trabalhadores é útil para a implantação de um comportamento condicionado favorável à produção. $\mathrm{O}$ sofrimento mental aparece como intermediário necessário à submissão do corpo" (Idem, p. 96).

Ao analisar o trabalho de telefonistas, Dejours mostra como a frustração provocada pelo trabalho gera maior disciplina e produtividade, voltando-se contra elas mesmas, pois "o trabalho não causa o sofrimento, é o sofrimento que produz o trabalho" (Idem, p. 103). Compreende que o sofrimento surge do conflito entre uma

[...] história individual, portadora de projetos, de esperanças e de desejos, e uma organização do trabalho que os ignora. Esse sofrimento, de natureza mental, co- 
meça quando o homem, no trabalho, já não pode fazer nenhuma modificação na sua tarefa no sentido de torná-la mais conforme às suas necessidades fisiológicas e a seus desejos psicológicos (Idem, p. 133, grifos do autor).

No caso do Direito, entendemos que complementando as diferentes histórias individuais, os projetos e as esperanças, a estrutura teórica e formal com o ideal de dever ser que a fundamenta submete promotores e magistrados a um sentimento de frustração derivado das situações cotidianas e recorrentes de conflito entre norma jurídica e realidade social. Todavia, dentre alguns termos recorrentes que aparecem neste campo, há uma ideia que suaviza as estruturas rígidas da forma jurídica, contextualiza-a no mundo dos possíveis da realidade social e afirma a existência de emoçóes que emergem do "abismo entre o juridicamente desejável e o socialmente possível".

Nesse sentido, ao falar sobre seu trabalho e alocação profissional, a juíza

1.Todos os nomes de juízes e promotores que aparecem neste trabalho foram modificados.
Cristina $^{1}$ explicou sua dificuldade em atuar na área Criminal e sua preferência pela área Cível, mediante o entendimento de que a primeira estabelece "um abismo entre o juridicamente desejável e o socialmente possível". Segundo ela, a área Criminal é um lugar onde se cumpre uma "formalidade simples e objetiva, mas cuja vida no cárcere está ligada a questôes sociais mais amplas". Diante desse descompasso, ela encontra dificuldade para condenar, visto que "a primeira ação do Estado na vida dessas pessoas foi para reprimir: não teve saúde, educação...”. Todavia, em face das obrigaçōes de sua profissão, não pode deixar de cumprir a lei, de condenar, utilizando uma base considerada não legal. Neste exemplo percebemos que, se o direito se impõe por meio de normas de dever ser, a juíza relativiza tal noção, criando um entendimento sobre o juridicamente desejável. Esse entendimento faz da decisão jurisdicional uma atividade mais complexa do que a simples formalidade de uma aplicação objetiva e racional do ordenamento jurídico. A frase utilizada relativiza a norma ao relacioná-la com as condições sociais que não permitem sua aplicação rigorosa, estrita; por outro lado, ela sofre na aplicação da norma porque a ação do Estado não condiz nem mesmo com o juridicamente desejável. A juíza finaliza com a afirmação do conceito de legalidade que a impede de deixar de cumprir a lei, em detrimento do social. A frustração é parte desse raciocínio, pois, ainda que apareça um desejo de atuação que possa fugir da legalidade, a realidade percebida nunca pode se sobrepor às imposições da lei e de seu cargo, mesmo que a lei seja relativizada e não cumprida em sentido estrito. 
Por esse descompasso, que incide predominantemente sobre as decisões criminais, a entrevistada prefere atuar na área Cível, acreditando que o socialmente possível é mais próximo ao juridicamente desejável. Trata-se de uma fala complexa e ambígua. Questiona a norma formal, contextualiza sua ação ao relacionar as possibilidades sociais de sua aplicação e incompatibilidades, mas retorna ao mundo do direito e ao distanciamento do social imposto pela norma jurídica. As fontes da frustração referem-se ao âmbito externo das condições sociais que limitam a previsão legal desejável.

Juridicamente desejável é uma relativização e adaptação da norma, um desejo - ainda que coletivo -, e não uma simples aplicação objetiva e racional. Mas esse desejo vai além do indivíduo, pois deve ser juridicamente justificado e limitado por aquilo que o campo jurídico - incluindo o Poder Executivo - circunscreve como condiçôes socialmente possíveis de sua aplicação e execução; é construído e possibilitado pelas discussões doutrinárias que orientam a interpretação e leitura da legislação, e pelos tribunais superiores que reformam ou acatam as sentenças dos juízes.

Estas ambiguidades entre o desejável e o possível, os conflitos pessoais e profissionais e as tomadas de posição, seja no campo do Direito, seja na leitura e na interpretação das leis ou do contexto social, percorrem os diferentes discursos com os quais tivemos contato: frustração com a profissão, com sua ação diante do real, com a área de atuação, frustração decorrente dos conflitos impostos entre o juridicamente desejável e o socialmente possível. Perguntamos à juíza Ellen, perguntamos "como ela se via” sendo juíza de execução, e obtivemos a seguinte resposta:

Frustrada! Tinha ideais... fiquei mal, tive que procurar psicólogo, tomar antidepressivo... Tudo foi frustrado! Pelo Poder Judiciário, pela Secretaria de Administração Penitenciária, pelo Sistema Carcerário. Não há vontade que funcione... Enquanto juiz, não se consegue fazer porra nenhuma... Frente a isto, depois de três anos comecei a ver de outra forma, de forma contemplativa. Se fizer alguma coisa a mais, esbarra em objeçôes.

Ela sintetiza o sentimento de frustração de um modo que é recorrente no campo, especialmente - não podemos esquecer - porque tínhamos como referência a discussão sobre o estuprador e as condições carcerárias. Embora a frustração tenha diferentes matizes, imaginar-se frustrado é uma característica muito forte na composição das variáveis que envolvem as emoções dessas atividades profissionais. No caso dessa juíza, o trabalho se traduz 
2. Gíria de presos que denomina as transferências dos indivíduos entre as instituiçôes carcerárias. De modo geral, "pegar o bonde" é utilizar a viatura de transporte para qualquer tipo de deslocamento. num sentimento que se volta contra ela e se materializa em conflitos psicológicos e pela necessidade de psicotrópicos. Todavia, ainda que apareça e se volte contra o indivíduo, o sentimento não é percebido como um problema individual, interno, mas é resultado dos conflitos envolvidos na administração do campo jurídico, seja o tribunal ou a administração penitenciária. Internamente, em termos dos seus ideais de justiça ou do próprio direito, é como se não houvessem problemas, pois a sua vontade seria de que as coisas funcionassem e que seu ideal se realizasse.

Movida pelo sentimento de frustração exteriormente imposto e pela impossibilidade de uma atuação que entendia correta, a juíza criou uma postura "de contemplação". Fez um movimento pessoal-profissional que partiu do idealismo, de desejos e esperanças de justiça e legislação para uma postura burocrática e mecânica, que não exige envolvimento ou paixão, mas somente o preenchimento de formulários e procedimentos burocráticos formais, afirmando a perda do sentido do trabalho. E, enquanto atividade judicante na área da execução penal, restringiu sua ação à avaliação e concessão de benefícios legais e de tempo de pena solicitado pelos presos, assim como a reivindicações corriqueiras ligadas a problemas com a comida e o tempero oferecidos na prisão.

Ao analisar a Lei de Execuções Penais (LEP) como atividade jurisdicional, a juíza Ellen afirma que houve restrições na alocação de condenados, e que só ficou sabendo do "bonde" 2 meses depois de ocorrido. Narra um caso que considera ainda pior e que se tornou divisor de águas, do idealismo à contemplação. Como juíza de execução, obteve informaçôes de que um estabelecimento de menor segurança, para presos com possibilidade de ressocialização, estava sendo usado para fugas, pois no lugar eram alocados presos graves. Quando impediu que isso ocorresse, sofreu representação do Tribunal:

O meu Tribunal me deu respaldo? Nada! Recebi telefonema do [...] dizendo que isto não era minha atribuição. Fui humilhada! Como vou lidar com isto senão de forma contemplativa? Entrei por idealismo. Não queria a respeitabilidade do juiz, dinheiro... Mas sofre-se muito! Tinha idealismo, não tenho mais.

Corroborando este olhar negativo sobre as condições da execução penal, o juiz Newton entende que "deveria ter estrutura para receber o preso, e assim pudessem aprender ofícios como marceneiro, funileiro... que recebessem salário". No entanto, diante do que acontece na execução penal, "se 
sente um otário, atuando em uma estrutura viciada". Fala num tom de crítica feroz, mas se rende aos contornos da sua atividade tendo uma postura burocrática no seu cotidiano. $\mathrm{O}$ problema está na execução, que seria responsabilidade do Executivo, e não na lei e no entendimento do Judiciário.

O juiz Rubens, em contrapartida, não se sente frustrado, mas acredita fazer o que é possível, e, dentro dos limites, tenta fazer o que pode. Fala da sua sala e que muitos móveis lhe pertencem, que o computador - até chegar um novo - era o dele também. Afirma que investiu muito do seu dinheiro particular para aperfeiçoar e criar condiçôes melhores de trabalho, tais como ar condicionado, mesa, cadeira e tapete, e que, perante as condições que tem, entende fazer o melhor.

De modo similar, o juiz Vilanova afirma:

É frustrante para quem acredita na justiça criminal. Qual é a função da justiça penal? Eu não me frustro! É um sistema de controle, seletivo, irracional. Todavia, o sistema penal pode ser visto como sistema de garantias, e neste caso não é frustrante. Se você consegue efetuar as garantias tem sentido, se o juiz no penal consegue se pensar tendo como função efetuar as garantias. Nesse sentido, o papel do juiz é conter o Estado para que o Estado não abuse. Isto me mantém como juiz criminal.

Vamos resolver os problemas sociais? O Sistema Penal serve para quê? Ele só cumpre uma função simbólica. Cria uma estrutura para enganar "trouxa”. Não soluciona problema nenhum e é ineficaz para resolver os problemas postos. Se você acreditar que vai resolver [...] se frustra mesmo.

Este juiz afasta-se da sensação de frustração por meio de um discurso de crença e descrença no trabalho e na justiça criminal. Respondendo negativamente à minha pergunta, recusa a frustração, mas de um modo que estabelece uma descrença na sua área de atuação profissional e no sentido do trabalho. Ambiguidade que constrói e desconstrói, afirma e nega o seu lugar simultaneamente. Sua consciência da ação da justiça leva-o a negá-la, ao mesmo tempo em que reivindica este lugar dentro dos possíveis, do socialmente possível. Justifica a ineficácia como uma forma de "enganar trouxa", e que não resolve problema nenhum, mas retoma a possibilidade de garantir direitos.

De modo semelhante a Rubens, afirma uma posição realista perante as incoerências e as dificuldades da atividade, mas se resguarda numa posição "garantista" do direito. Ao mesmo tempo em que nega o sentido do trabalho 
ante seus valores pessoais e a crítica que o social lhe impõe, reafirma a profissão, justificando-a por meio de uma teoria jurídica sobre a prática, protegendo-a da falta de sentido que ele próprio admite existir na profissão.

Quando expusemos a questão da frustração na ação profissional na área Criminal, e em relação à concepção dos juízes Newton, Cristina e Riobaldo, que consideravam a justiça civil o único campo onde ainda era possível se fazer justiça, o promotor Célio discordou, afirmando sua posição nos conflitos de competência e revelando conflitos intraprofissionais:

No Cível é ainda pior. No processo criminal existe um tempo que dura no máximo um ano, e nesse período a pessoa vai saber se é culpada ou inocente. Agora, tem processo Cível de vinte, trinta anos.

Exemplifica com um caso de falência de uma empresa onde os bens viraram sucata. "Se fosse crime, já tinha cumprido a pena, pois no crime tem prescrição. Agora, o Cível tem o tempo que for". E continua, afirmando uma racionalidade voltada ao fim:

Isto é postura hipócrita! No Crime tem começo, meio e fim. A vítima e o réu vão saber do fim. E se não tiver feito, o réu vai ser solto [...]. O Criminal dá uma resposta: bem ou mal, dá. O Criminal quer saber se é culpado ou inocente. Ele dá uma solução. Pelo menos até a sentença.

Neste emaranhado de conflitos e diferentes posiçôes entre o 'juridicamente desejável e o socialmente possível', o campo jurídico possibilita opções e saídas que, além de um sentimento de frustração, apresentam possibilidades de funções diferenciadas e que afastam este sentimento. Assim, o juiz Riobaldo afirma sua preferência pela Vara de Família em oposição à Criminal.

Eu estou na Família. É onde se está mais próximo e causa um impacto efetivo pela atuação. Tem contato pessoal, sempre. São questões humanas onde a conciliação é importante e a efetivação da decisão é mais visível: casamento, interdição e desinterdição [sic] de pessoas. As pessoas também odeiam juiz de família, pois impóe direito de visita, manda o cara para fora de casa. Diferente do Cível, que demora anos e falta efetividade. Quando há consenso é uma delícia! Na Família fico mais gratificado. 
Neste conflito intraprofissional das diferentes competências, ele afirma que na área Criminal a atividade é ouvir testemunha, analisar provas e confirmar a investigação da polícia, julgando-a procedente ou não. Entende a área Criminal como mais confortável, pois seu papel é controlar as legalidades. Conforto no sentido de ação burocrática, como ação de prescrição e de adequação à norma legal, em oposição ao contato mais próximo e de decisão com efetividade mais evidente, no sentido de ser preciso poder acompanhar o desenrolar do processo e de aproximação das normas jurídicas. Dessa maneira, ele se afasta do sentimento de frustração que afirma existir na esfera Criminal: atuação burocrática voltada ao fim, distanciada das pessoas e sem o sentido de trabalho intelectual de reflexão, como se dá sob a influência do "meio" processual.

Inserindo-se no quadro mais amplo de frustraçōes, a juíza Vera salienta a variável classe social que transpassa as decisões e a atuação na justiça:

Crime tributário, de colarinho branco, a legislação não pega. É difícil condenar alguém, pois o esquema permite. No caso dos pobres fica difícil usar os recursos, pois, se quiser entrar com recurso especial tem que mandar para Brasília. Todavia, não posso e nem devo deixar de condenar a classe mais baixa porque não consigo condenar a classe alta. Isto gera frustração!

E, de modo mais específico:

Eu sofria muito no crime [quando atuava na vara criminal]. Se encontrava alguém mal defendido, eu voltava e mandava refazer a instrução. Agora, como se pode fazer isso com dez mil processos? O juiz que tem processo em dia é porque trata o caso concreto com muita superficialidade, porque tem pressa de chegar ao $\mathrm{fim}^{3}$. Na verdade, dão uma solução para o processo, não para o problema.

Segundo o juiz Almeida, "a justiça é para pobre, pois o rico tem condições". Também se vê frustrado com o crime, pois "é uma bola de neve. Trabalho pontual. Póe o cara na cadeia e só”. Como se fosse uma produção de novos criminosos, sem o papel de recuperação.

Tanto no sentido dos limites de classe social ao qual a justiça se dirige, como nos limites da ação de recuperação do preso, a intervenção de juízes e promotores é permeada pela impotência perante as condições processuais e a execução penal que não têm controle, seja por não prenderem os ricos, seja por prenderem somente pobres.
3. A partir de uma pesquisa realizada na Vara de Execução Penal de São Paulo, Guilherme de Souza Nucci (2005), apesar dos sérios problemas metodológicos em sua pesquisa, procura mostrar que os(as) juízes(as) não fundamentam a aplicação da pena. O problema é que o autor não define o que entende por pena fundamentada. 
4.Em vários momentos, diferentes juízes e promotores diziam que o problema da prisão dependia do Estado. Mas o que é Judiciário em sua visão? Como não fiz esta pergunta, fica a questão: o Judiciário não se percebe como "Estado"?
Ao falar sobre o sofrimento que acompanha a ação profissional, o promotor Viana entende que "tem muito juiz e promotor que acabam em psiquiatras: a justiça não consegue cumprir a sua missão e se torna muito parecida com o Estado" ${ }^{4}$. Nesse sentido, a crise psicológica que a juíza Ellen relata não é um problema individual, mas faz parte das doenças decorrentes da profissão, assim como produz uma forma de trabalho. $\mathrm{O}$ trabalho no crime requer ação distanciada, burocrática e de massa, voltada ao fim sentença, solução de processo e não dos problemas. Assim, eles deixam para trás o "ideal”, ou a "missão" - e este perfil emocional é produzido ou reforçado -, tornando-se produtivos e capazes para o volume de processos aos quais estão expostos e em que devem decidir ou atuar.

Por outro lado, a partir de sua atuação profissional Viana entende que no Cível a frustração é maior, pois, quando se trata de recuperação de dano, o processo não se encerra. "Vários anos julgando, entra impugnação, não executa. O Penal, bem ou mal, chega ao fim. Às vezes, o Cível é mais relevante do que o Penal, pois se há negação de direito no Cível, se atinge família ou necessidades familiares, a situação pode ser ainda mais grave".

Os dois promotores valorizam a atuação na área Criminal em oposição à área Cível. A concepção das suas atividades a partir do viés tempo de processo e sentença, e não da fase de execução ou de um ideal de justiça, leva a um encadeamento do juridicamente desejável ao cumprimento de prazos burocráticos e formalidade processual. Ao contrário do discurso daqueles que estão no Cível, ou Família, que, por outro lado, não conseguem cumprir os prazos necessários para a própria realização da prestação jurisdicional.

A juíza Cristina afirma que atuar na área Criminal é horrível, pois com o encarceramento os indivíduos saem da prisão piores do que quando entraram. Acredita que há uma falência do sistema prisional e que a recuperação com pena não existe, pois os que passam por esse sistema ficam ainda mais marginalizados, e, por isso, o juiz se sente frustrado, como se não estivesse cumprindo papel nenhum.

A juíza Vera reafirma que é uma função frustrante. "Nada é bom. Nada do que deveria ser, pois a lei não é seguida. Só atua se alguém estiver batendo em preso. Qualquer coisa que se faça, aparece como sendo ingerência do Judiciário no Executivo". Faz referência a uma pesquisa publicada no jornal $A$ Folha de S. Paulo, segundo a qual, $40 \%$ da população entendia que o Judiciário era culpado pela situação dos presos. "Todavia, o juiz vai, olha. Pode até encaminhar cópia para o Ministério Público se, por exemplo, houver abuso de autoridade. Mas, do ponto de vista prático, não pode fazer nada”. 
Trabalho das emoções

A partir de uma etnografia realizada em escritórios de advocacia na regiáo de San Francisco, Estados Unidos, Jennifer Pierce (1995) analisa dois modelos de profissão jurídica, e estabelece duas formas contrapostas de relação entre atividade profissional, gênero e trabalho das emoções. De um lado, advogados formados e majoritariamente homens, que ocupam cargos de comando e poder; de outro, suas assistentes, na maioria mulheres, que ocupam o cargo subordinado de "paralegais" (paralegals- pessoas que atuam em área auxiliar do direito, sem terem formação jurídica).

Das mulheres espera-se um extraordinário suporte emocional aos advogados por meio de deferências e cuidados, administrando, por exemplo, sentimentos de raiva dos advogados e delas próprias. Pierce demonstra que "a estratificação de gênero nos escritórios de advogados reproduz as relações de gênero por meio dos requisitos emocionais necessários para a posição paralegal" (1999, p. 139). Dessas mulheres exige-se um trabalho emocional que implica atividades de maternagem (mothering), de trato e de cuidado (caretaking) dos advogados, que são superiores a elas em poder e rendimentos salariais. Por outro lado, dos advogados - que atuam em área de litígio (litigation, adversarial model) nos tribunais - espera-se a solicitação do cuidado das "paralegais, assim como comportamentos e sentimentos denominados gamesmanship, Rambo litigator. forma de comportamento e ação de controle e manipulação dos outros por intimidação ou por cordialidade estratégica, no trato com clientes, testemunhas, juízes e outros advogados nos tribunais (1995, p. 57-60).

O conceito de trabalho emocional foi elaborado por Arlie Hochschild para definir o "processo no qual as pessoas tomam como referência um padrão de sentimento ideal construído na interação social, e procuram manusear e administrar suas emoções profundas para adequá-las a essa expectativa quando não estão sentindo assim internamente" (Bonelli, 2003, p. 357, apud Hochschild, 2003, p. 7). A pesquisa de Hochschild foi realizada com aeromoças e cobradores, e mostra como esses empregados tinham que produzir ou reprimir sentimentos profundos, de forma a exprimir sorrisos constantes para os clientes das empresas aéreas - nicer than natural-, ou uma ferocidade ameaçadora direcionada aos devedores - nastier than natural (Steinberg e Figart, 1999). O importante nesse conceito é a elaboração de sentimentos dirigidos aos outros, e que se diferenciam de acordo com gênero, objetivando criar valor econômico, afetar a produtividade e gerar lucro 
(Hochschild, 2003, p. 17). Segundo Bonelli, a importância do trabalho de Hochschild está em articular o "impacto macrossocial do capitalismo nas sociedades avançadas sobre a dimensão microssocial do trabalho das emoções que os seres humanos realizam" (2003, p. 369).

Com base na abordagem do conceito de trabalho emocional, nos dados coletados no campo, assim como no conflito entre expectativa normativa, prática forense e execução penal, deseja-se salientar a relação entre atividade profissional e produção de emoções e sentimentos. Inicio com a perspectiva de Dejours, e a relação entre trabalho e doença individual, para evidenciar como o sofrimento expresso pelos juízes e promotores é parte da organização do trabalho e do conflito entre prescriçôes legais e condições sociais de sua realização.

Embora dados significativos sobre a produção de emoções e gênero não estejam disponíveis, percebe-se que as mulheres não só falam mais sobre o sentimento de frustração do que os homens, como também esse tipo de discurso aparece entre elas de forma mais espontânea, exprimindo um sentimento mais presente e profundo.

Ainda que os homens tenham falado de frustração, eles como que repetiam um discurso de senso comum do campo jurídico - prova de consciência social em oposição ao caráter técnico e burocrático da aplicação da lei. Trata-se, em alguns momentos, de uma obrigatoriedade formal de se mostrarem conscientes das imperfeiçôes e dos abismos entre legislação, prática forense e práticas efetivas e degradantes da execução penal.

Não obstante Pierce afirmar que "o mesmo trabalho, não é o mesmo trabalho para homens e mulheres" (1995, p.177), não foi possível verificar as formas de diferenciação nas atividades profissionais, especialmente porque não estamos lidando com uma hierarquia profissional e de gênero tão demarcada quanto aquela analisada pela autora. Todavia, pensando num mesmo nível hierárquico - como ocorre entre juízes e juízas, promotores e promotoras - é necessário avaliar, posteriormente, se há diferença de gênero nas escolhas - e quais critérios de escolha - das diferentes as áreas de atuação na magistratura e no Ministério Público. Ou seja, haveria uma inclinação para as áreas de justiça Civil e de Família, por parte das mulheres, enquanto os homens "dominariam" a área Criminal? Ou, como vimos, entre aqueles que afirmam procurar justiça, valores e ideais, atenção e cuidado no desenvolvimento e no acompanhamento do processo e aqueles que procuram por procedimentos técnicos, burocratizados e mais céleres de decisão? 
Existe, portanto, uma associação entre a forma de atuação, a área de conhecimento e o gênero. Do mesmo modo que Pierce, ao pensar sobre possíveis mudanças nos comportamentos e na segregação sexual que encontrou nos escritórios de advocacia, questiona a necessidade de transformação do próprio direito:

[...] nós devemos repensar o próprio modelo contencioso de direito. A ética do gamesmanship, isto é, ganhar o caso usando de quaisquer meios, ainda que na forma da lei, favorece uma relação calculada e estratégica entre os advogados e a audiência jurídica (1995, p.186).

\section{Conclusão}

Como anunciei no início deste trabalho, o pano de fundo das discussões e entrevistas com juízes e promotores foi o contexto de sujeição dos estupradores à violência no cárcere e as condições da execução penal. Este é um contexto que afronta fortemente a legislação e o ideal de direito juridicamente normatizado. Com base nos dados, diante das dificuldades para se atuar e do descompasso que a legislação define como dever ser, cria-se um sentimento de impotência no indivíduo em face do social que não se deixa encaixar nas previsōes legais ideais. Por isso também se fala do socialmente possível, pois ele pode amenizar as frustrações do direito, transformando-o em juridicamente desejável.

De modo geral, o que perturba o ideal jurídico é a sua estrutura de funcionamento que se volta de forma desigual para as diferentes classes sociais, seja punindo com exclusividade os pobres, seja na dificuldade de punir os ricos. São as condiçôes do cárcere que não respeitam a Lei de Execuções Penais, criam novos criminosos, não recuperam e são punitivas. É o Executivo, responsabilizado como incapaz de cumprir as diretrizes da execução penal, assim como o Legislativo que não faz legislação adequada. Aspectos que podem aparecer como fora da ordem e inadequados, mas cujos limites teóricos e profissionais do dever ser impedem de atuar de forma contrária ao que o campo jurídico define como aplicação da lei, ainda quando contrariem aspectos da própria ordem normativa.

Entre as diferentes áreas de atuação, como Cível e Criminal, há uma "disputa" em relação a quem estaria cumprindo de forma mais adequada o juridicamente desejável. Aqueles que estão na Cível afirmam que conseguem resolver os conflitos e se aproximam do ideal de justiça, em oposição 
às formas degradantes da execução penal, e de uma atuação mecânica e burocrática que localizam na área Criminal. Aqueles que estão na Criminal salientam a morosidade da Cível, a falta de prestação jurisdicional e o descompasso temporal referente às necessidades processuais, valorizando o resultado burocrático e a forma que restringe o tempo de processo criminal. Ainda que esses conflitos articulem o campo de atuação profissional e de legitimação da ação jurídica de maneiras diversas, eles permitem que juízes(as) e promotores(as) se afirmem como cumpridores da lei, embora submetidos ao peso e às contradições do socialmente possível.

Os constrangimentos da prática fazem com que os(as) juízes(as) e promotores(as) sofram, frustrem-se com os limites do real, ou transformem as frustrações num mundo do que é construído como socialmente possível. Isso pode levar a uma postura profissional que implica desgosto e desencanto com a profissão; uma atitude de distanciamento e insensibilidade para com os problemas que enfrentam; à falta de paixão e ao procedimento estritamente burocrático; ao reconhecimento dos limites da competência e à atuação positiva; à atribuição dos problemas a outras instâncias de poder, como o Executivo ou Legislativo; ou ainda, ao sofrimento por problemas psicológicos e depressão. Embora existam outros sentimentos não considerados neste trabalho, podemos afirmar que a construção, a incorporação, a manipulação e a expressão do sentimento de frustração são partes constitutivas da formação do devir profissional e da produção profissional nos limites do campo jurídico analisado.

\section{Referências Bibliográficas}

Associação dos Magistrados Brasileiros. Pesquisa AMB 2005. Disponível em <www.amb.com.br/portal/docs/noticias/PesquisaAMB2005.pdf>, consultado em 20/10/2006.

Barros, Carmen Silvia de Moraes. (2001), A individualização da pena na execução penal. São Paulo, Revista dos Tribunais.

Bitencourt, Cezar Roberto. (2006), Tratado de direito penal: parte geral. 10 ed. São Paulo, Saraiva. vol. 1.

Bonelli, Maria da Gloria. (1998), "A competição profissional no mundo do direito". Tempo Social, 10 (1): 185-214, maio.

. (2003), "Arlie Russell Hochschild". Cadernos Pagu, 21: 357-372.

. (2005), "Ideologias do profissionalismo em disputa na magistratura paulista”. Sociologias, Porto Alegre, ano 7 (13): 110-135, jan./jun. 
. (2001), "Os desembargadores do Tribunal de Justiça do Estado de São Paulo e a construção do profissionalismo: 1873-1997”. Dados, Rio de Janeiro, 44 (2). Disponível em <http://www.scielo.br/scielo.php? script=sci_arttext\&pid=S001152582001000200002\&lng=en\&nrm=iso $>$, consultado em 22/09/2006.

Bourdieu, Pierre. (2002), A dominação masculina. Trad. Maria Helena Kuhner. 2 ed. Rio de Janeiro, Bertrand Brasil.

. (1989), O poder simbólico. Trad. Fernando Tomaz. Lisboa, Difel.

Brasil. (2006), "Supremo Tribunal Federal. Banco Nacional de Dados do Poder Judiciário - BNDPJ". Justiça comum de $1^{\circ}$ grau. Disponível em <www.stf.gov.br/ bndpj/justicacomum/Jcomum7A2003.asp>, consultado em 13/11/2006.

. (2007), "Lei complementar n. 35, de 14 de março de 1979". Dispõe sobre a Lei Orgânica da Magistratura Nacional. Disponível em <http://www.planalto. gov.br/ccivil_03/Leis/LCP/Lcp35.htm>, consultado em 23/2/2007.

. (1995), Código penal e sua interpretação jurisprudencial. In: Franco, Alberto Silva et. al. São Paulo, Revista dos Tribunais.

Caldeira, Teresa. (1988), "A presença do autor e a pós-modernidade em antropologia”. Novos Estudos Cebrap, (21): 133-157, jul.

CARdoso, Ruth C. L. (1986), A aventura antropológica: teoria e pesquisa. Rio de Janeiro, Paz e Terra.

Dejours, C. (1992), A loucura do trabalho: estudo de psicopatologia do trabalho. Trad. A. I. Ferreira. São Paulo, Cortez/Oboré.

Dimoulis, Dimitri. (2003), "Manual de introdução ao estudo do direito: definição e conceitos básicos; norma jurídica; fontes, interpretação e ramos do direito; sujeito de direito e fatos jurídicos; relações entre direito, justiça, moral e política; direito e linguagem”. Revista dos Tribunais, São Paulo.

. (2006), Positivismo jurídico: introdução a uma teoria do direito e defesa do pragmatismo jurídico-político. São Paulo, Método.

Feldman-Bianco, B. (org.). (1987), A antropologia das sociedades contemporâneas. São Paulo, Global.

Hochschild, A. R. (2003), The managed heart: commercialization of human feeling. 20 ed. Berkeley/Los Angeles/Londres, University of California Press.

Kelsen, Hans. (1998), Teoria pura do direito. 6 ed. São Paulo Martins fontes.

Malinowski, B. K. (1984), Argonautas do Pacífico ocidental: um relato do empreendimento e da aventura dos nativos nos arquipélagos da Nova Guiné Melanésia. 3 ed. São Paulo, Abril Cultural.

MarCÃo, Renato. (2006), Curso de execução penal. 3 ed. São Paulo, Saraiva.

Mirabete, Julio Fabbrini. (1992), Execução penal: comentários à Lei n. 7.210, de 1107-84. , São Paulo, Atlas. 
Nucci, G. S. (2005), “Individualização da pena”. Revista dos Tribunais, pp. 413431.

Pierce, J. L. (2002), “'Not qualified' or 'not committed': a raced and gendered organisational logic in law firms". In: Banakar, R. \& Travers, M., An introduction to law and social theory. Oxford, Hart Publishing.

. (1999), "Emotional labor among paralegals". The Annals of the American Academy of Political and Social Science, 561: 127-142, jan.

. (1995), Gender trials: emotional lives in contemporary law firms. Berkeley/Los Angeles/Londres, University of California Press.

SAdek, Maria Tereza. (2002), "Estudos sobre o sistema de justiça”. In: Miceli, Sergio (org.), O que ler na ciência social brasileira. São Paulo/Brasília, Anpocs/Sumarél Capes, pp. 233-265.

(org.). (2000), Justiça e cidadania no Brasil. São Paulo, Sumaré/Idesp. (org.). (1997), O ministério público e a justiça no Brasil. São Paulo, Sumaré/Idesp. (org.). (1995), Uma introdução ao estudo da justiça. São Paulo/Rio de Janeiro/ Nova York, Idesp/Sumaré/Fundação Ford/Fundação Mellon.

SteinberG, R. J. \& Figart, D. M. (1999), "Emotional labor since: the managed heart". The Annals of the American Academy of Political and Social Sciences, 561: $9-26$.

Vianna, L. W. et. al. (1999), A judicialização da política e das relaçôes sociais no Brasil. Rio de Janeiro, Revan.

Vianna, L. W. et. al. (1997), Corpo e alma da magistratura brasileira. 3 ed. Rio de Janeiro, Revan. 


\section{Resumo}

\section{A frustração profissional e a lei}

O objetivo deste artigo é analisar alguns conflitos emocionais que o sistema de direito positivo impõe a magistrados e promotores dentro do campo jurídico. Tendo como parâmetro o cotidiano profissional, assim como as ambiguidades que surgem entre o ideal jurídico e as práticas efetivas da execução penal, mostraremos que o sentimento de "frustração" constitui parte significativa do discurso sobre as emoções que caracterizam esta profissão.

Palavras-chave: Profissão jurídica; Conflitos profissionais; Trabalho das emoções.

\section{Abstract}

Professional frustration and the law

The objective of this article is to analyze some emotional conflicts that the civil law tradition imposes on magistrates and district attorneys within the judicial field. Based on research into the everyday practice of the profession and the ambiguities that emerge between the juridical ideal of law and the effective practices of penal enforcement, this study shows that a feeling of "frustration" underpins much of the discourse concerning the emotions that characterize this profession.

Keywords: Legal profession; Judicial field of law; Professional conflicts; Emotional labor.
Texto recebido em 16/ 2/2009 e aprovado em 9/3/2010.

Gessé Marques Jr. é doutor em Sociologia (USP) e professor na Universidade Metodista de Piracicaba (Unimep). E-mail: <gessem qs@gmail.com>. 